Katarzyna Olbrycht*

Cieszyn

\title{
Nowy humanizm Jana Pawła II jako perspektywa dla współczesnej rzeczywistości szkolnej i wychowawczej
}

\begin{abstract}
Dobra szkoła - to przede wszystkim mądra szkoła. Niechaj w pracy wychowawczej wszyscy zaangażowani w nią ludzie, zarówno wierzący, jak poszukujący i niewierzący, poczują się związani najpiękniejszym zadaniem - zadaniem cierpliwego i pełnego spokojnej mądrości ukazywania dojrzewającym ludziom, jak być człowiekiem naprawdę ${ }^{1}$.
\end{abstract}

Karol Wojtyła

Wychowanie jest jedną z najważniejszych i najtrudniejszych sfer rzeczywistości ludzkiej. Wszystkie środowiska wychowawcze, tradycyjnie wyodrębniane przez nauki o wychowaniu, zmagają się dziś z rosnącymi trudnościami i dylematami dotyczącymi tego, na czym ma polegać wychowanie odpowiadające potrzebom współczesnego świata. Środowiskiem, które w największym stopniu może zaprogramować i planowo realizować działalność wychowawczą, współpracując z rodziną i wspomagając

* Prof. zw. dr hab. Katarzyna Olbrycht jest kierownikiem Zakładu Edukacji Kulturalnej w Wydziale Etnologii i Nauk o Edukacji Uniwersytetu Śląskiego w Cieszynie.

${ }^{1} \mathrm{~K}$. Wojtyła, List Pasterski o powołaniu nauczyciela $i$ wychowawcy (Kraków 30.09.1972), za: W. Chudy, Pedagogia Godności. Elementy Etyki Pedagogicznej, Lublin 2009, s. 212. 
ja, jest szkoła. Równocześnie obserwuje się rosnącą krytykę tej instytucji, zarówno od strony funkcjonowania, jak i efektów. W powszechnej opinii środowisk oświatowych, szczególnie trudnym wyzwaniem edukacyjnym okazało się gimnazjum. Poszukiwanie skutecznych metod i form pracy na tym szczeblu kształcenia nie przynosi pożądanych rezultatów. Gimnazjum, uważane często za najsłabsze wychowawczo ogniwo systemu szkolnego, jest równocześnie wskaźnikiem ogólniejszej wychowawczej słabości szkoły.

Sensem każdej instytucji społecznej jest pełnienie funkcji, dla której została powołana do życia. W przypadku szkoły jest to najogólniej mówiąc system celowych działań i wzajemnych oddziaływań, które stwarzają edukowanemu człowiekowi warunki do własnego rozwoju oraz przygotowuja go do życia w społeczeństwie. Szczegółowa treść tej funkcji zależy więc $\mathrm{z}$ jednej strony od sposobu rozumienia czlowieka, istoty jego rozwoju, a tym samym sprzyjających i niesprzyjających temu rozwojowi warunków, z drugiej - od pożądanego kształtu życia społecznego i służących mu kompetencji jego uczestników.

Nie ma edukacji całkowicie „neutralnej” pod względem celów i wartości, jakim cele te mają służyć, a tą drogą kształtować określonego człowieka. Nie ma też szkoły całkowicie neutralnej aksjologicznie. Uzyskanie takiego stanu w rzeczywistości edukacyjnej nie jest możliwe, co podkreślało na przestrzeni dziejów myśli pedagogicznej wielu teoretyków i praktyków wychowania. Szkoła, bez względu na programowe deklaracje, poprzez dobór treści nauczania, metod, form i środków, poprzez relacje międzyludzkie jakie buduje, przykłady zachowań jakie prezentuje, postawy jakie nagradza i karze - kształtuje określonego człowieka. Nawet programowe uwolnienie rozwijającej się jednostki od realizowania wyraźnych celów i wartości, w świetle psychologii rozwoju człowieka jest fikcja, ponieważ drogą nakładania się wielu różnorodnych działań i oddziaływania wielu przypadkowych nawet czynników zawsze będzie następowało wzmacnianie jednych, a osłabianie innych wartości.

W świetle analizy obserwowanych w dzisiejszej szkole mechanizmów i praktyk pojawia się niepokój o to, jaki człowiek jest w niej i przez nią kształtowany, jaki obraz społeczności szkolnej - uczniów, nauczycieli i rodziców - wyłania się z głębszej analizy współczesnej rzeczywistości szkolnej. Określające ją i kształtujące programowe dokumenty odwołują się między innymi do przyjętych przez Radę Europy kompetencji kluczowych ${ }^{2}$,

${ }^{2}$ Kompetencje kluczowe w uczeniu sie przez cate życie. Dokument Rady Europy wydany w $2006 \mathrm{r}$. 
mających zapewnić równość podstaw edukacyjnych i szans rozwoju wszystkich Europejczyków. Kompetencje te opierają się na czterech zasadniczych zakresach: przygotowania do samorealizacji i rozwoju osobistego, do aktywności obywatelskiej, integracji społecznej i rynku pracy. Znamienne jest, iż praktyka edukacyjna skoncentrowała się na ostatniej z kompetencji, nie poświęcając większej uwagi rozwojowi osobistemu, który - zależnie od koncepcji człowieka i jego rozwoju - będzie w ogromnym stopniu wyznaczał funkcjonowanie społeczne i obywatelskie. Koncentrowanie całej uwagi na skuteczności, efektywności, kształceniu kompetencji przydatnych najpierw w karierze szkolnej a potem zawodowej sprawia, że traci się z oczu zasadnicze pytania: o kogo ostatecznie chodzi? O jakiego człowieka? Ale i pytanie: jaki człowiek może kształtować innych?

Wydaje się, że w obecnej sytuacji coraz wyraźniejszego narastania w życiu społecznym, w tym w edukacji, antropologicznej dezorientacji, ważnych wskazań oraz inspiracji do programowania i prowadzenia pracy wychowawczej może dostarczyć spojrzenie na wychowanie z perspektywy nowego humanizmu Jana Pawła II.

\section{Nowy humanizm Jana Pawła II}

Wypychanie pytań antropologicznych - bo o nie tu chodzi - z głównego nurtu debaty społecznej nie jest zjawiskiem występującym wyłącznie w rzeczywistości oświatowej, choć tu ma szczególne znaczenie. Cechuje generalnie współczesną kulturę. Na ten właśnie jej aspekt i powstające na tej drodze zagrożenia zwracał uwagę przez cały okres swego pontyfikatu Jan Paweł II.

Przełom wieków i tysiącleci nie przyniósł wyraźnej, radykalnej przemiany świata i bardziej refleksyjnego stosunku do człowieka, świadomie przyjmowanej antropologii, choć świat zachodni powszechnie przyjmuje ideę humanizmu jako uznawania najwyższej wartości człowieka. Znana filozofka francuska Chantal Delsol w opublikowanej w 2008 roku książce Czym jest człowiek? formułuje jeszcze bardziej radykalną diagnozę. Według tej autorki, mimo przyjmowania idei humanizmu jako oczywistej podstawy praw człowieka, współczesny świat przestaje się zajmować antropologią filozoficzna, odrzuca potrzebę namysłu nad przyjmowaną koncepcją człowieka i jej konsekwencjami. Myślenie wyłącznie w kategoriach różnic kulturowych neguje dziś sens szukania istoty człowieka i człowieczeństwa, tym samym - antropologii filozoficznej. Autorka zwraca jednak uwagę, iż to właśnie określona antropologia filozoficzna daje podstawy humanizmu. Pisze: „Humanizm jest związany z antropologią w takim sensie, że trzeba 
mówić o człowieku, aby ustalić normy szacunku dla niego, aby wiedzieć, kim jest człowiek, którego mamy szanować"3.

Przywołanie Jana Pawła II w ramach debaty nad dzisiejszym stanem szkoły i edukacji jest w tym kontekście uzasadnione nie tylko, i nie w pierwszym rzędzie, faktem, iż jest nadal uznawany przez wielu ludzi na świecie, niezależnie od światopoglądu, za ważny autorytet. To są oczywiście ważne racje i niejako uczuciowe zobowiązania. Jednakże najważniejszą racją jest zwrócenie przez Jana Pawła II uwagi współczesnego świata na konieczność powrotu do człowieka, do namysłu nad jego istota, do rozważenia sensu jego rozwoju i warunkujących go czynników, sformułowania antropologii, która nie pogrążałaby $\mathrm{w}$ bezsensie, ale pokazywała podstawy nadziei. Mimo powracających w wielu współczesnych nurtach kulturowych i ideologiach haseł humanizmu, wielość możliwych jego interpretacji wyrastających ze skrajnie różnych koncepcji człowieczeństwa i programów jego rozwijania prowadzi w konsekwencji do utraty zaufania do konkretnego wpływu tej idei na życie ludzi i społeczeństw.

Wielu badaczy pontyfikatu polskiego Papieża podkreślało i podkreśla przełomowy charakter formułowanej przez Niego antropologii. W epoce pogoni za nowymi technologiami i instrumentalnymi kompetencjami, które mogłyby im służyć, wołanie o człowieka, jego godność, obrona jego podmiotowości, została uznana za „nowy humanizm”, co było zgodne z określeniem używanym przez samego autora - Jana Pawła II. Wyjaśniał On między innymi młodzieży: „Miarą postępu ludzkości nie są zdobycze technologii, ale raczej stopień wrażliwości moralnej osiagnięty przez jej członków"4. Podkreślał, że tworzenie kultury musi polegać na tym, by uznanie dla skuteczności szło w parze z rozwojem osobowości każdego człowieka. „Trzeba zapoczątkować nowy humanizm, w którym cenne osiągnięcia czasów współczesnych zostaną zintegrowane $\mathrm{z}$ trwałymi wartościami chrześcijańskiej koncepcji człowieka"s.

Wyjaśnienie sensu nowego humanizmu Jana Pawła II można odnaleźć w kilku dopełniających się obszarach: obszarze prac filozoficznych nad antropologią człowieka podejmowanych jeszcze przez Karola Wojtyłę, nauczania kierowanego już przez papieża Jana Pawła II do ludzi wszystkich środowisk, narodów i części świata, apeli do ludzkości przełomu wieków XX i XXI, których adresatem były między innymi największe międzynaro-

${ }^{3}$ Ch. Delsol, Czym jest człowiek?, tłum. M. Kowalska, Kraków 2011, s. 13.

4 Jan Paweł II, Wspólnie realizujcie projekt humanizacji świata, Florencja, Anioł Pański, przemówienie do młodzieży 19.10.1986 [4,6], w: Podręcznik Pokolenia JPII. Ojcowskie stowo do młodych świata, Polski i Lednicy, Poznań 2008, s. 279.

5 Tamże, s. 281. 
dowe gremia (UNESCO, ONZ, Międzynarodowy Trybunał Praw Człowieka, Międzynarodowa Organizacja Pracy, FAO, Unia Międzyparlamentarna).

Nowy humanizm Jana Pawła II, uznając wartość człowieczeństwa, które wymaga stałego rozwoju i aktualizacji, dopowiada zarówno istotny sens bezwarunkowej wartościowości przysługującej każdemu człowiekowi, jak i jej źródła oraz uzasadnienie. Istotą jest osobowa godność każdej istoty ludzkiej, oparta na jej rozumności i wolności, wymagająca bezwarunkowego uznania i szacunku. Wynikające z niej dążenie do prawdy, dobra i piękna stanowi duchowy wymiar człowieka. Wymiar ten jest niejako zwieńczeniem pozostałych wymiarów istoty ludzkiej - to znaczy wymiaru fizycznego i psychicznego. Koncepcja człowieka jako osoby zakłada integralność wszystkich tych trzech wymiarów. Uzasadnienie godności ludzkiej wynika z chrześcijańskiego widzenia człowieka jako obrazu Boga. Obejmuje ono równocześnie interpretację zasadniczych wartości, do których dąży człowiek, realizując swoje człowieczeństwo. Nowy humanizm Jana Pawła II odwołuje się więc do: antropologii filozoficznej - jako personalizm (koncepcja człowieka jako osoby) i teologii chrześcijańskiej - jako chrześcijański humanizm.

Zdaniem wielu autorów zajmujących się pontyfikatem Jana Pawła $\mathrm{II}^{6}$, źródeł programu tego pontyfikatu trzeba szukać już u Karola Wojtyły, według którego najważniejszym wyzwaniem dla współczesnych chrześcijan i Kościoła było budowanie nowego, chrześcijańskiego humanizmu. Określona w ten sposób koncepcja człowieka miała być odpowiedzią na współczesne zagrożenia człowieczeństwa, które Wojtyła dostrzegał i analizował od początku swojej działalności duszpasterskiej a potem również naukowej. Jan Paweł II, jeszcze jako filozof, stwierdzał, że podstawowym zagrożeniem jest rosnące we współczesnym świecie niezrozumienie istoty człowieka, sensu i celu jego życia, a co za tym idzie - istoty rodziny, wartości wspólnoty. Niezrozumienie to było wywołane przez dominujące w XX wieku nurty filozoficzne i ideologie społeczno-polityczne.

Włoski filozof i polityk Rocco Buttiglione, analizując twórczość filozoficzną Karola Wojtyły, którą uważał za przełomową dla współczesnej refleksji o człowieku, tak charakteryzował czas jej powstawania:

Konflikt znaczący historię współczesną jest konfliktem «za» lub «przeciw» chrześcijańskiemu obrazowi człowieka. Różne formy totalitaryzmu starają się zbudować państwo ludzkie bez Boga, w którym (niezależnie od roszczeń do

${ }^{6}$ Por. prace R. Buttiglioniego o dorobku filozoficznym Karola Wojtyły a także analizy pontyfikatu Jana Pawła II G. Weigla, głównie: Świadek nadziei. Biografia papieża Jana Pawta II, Kraków 2000. 
humanizmu pewnych form totalitaryzmu) człowiek jest nieuchronnie sprowadzony do roli narzędzia władzy?

Zdaniem Buttiglioniego, a także wielu innych badaczy spuścizny Karola Wojtyły, zaproponowany przez Niego personalizm był pierwszą na gruncie polskiej filozofii i niezwykle oryginalną na gruncie rodzącego się personalizmu europejskiego próbą przezwyciężenia groźnych trendów kulturowych, redukujących człowieka do istoty biologicznej lub społecznej, prowadzących ostatecznie do totalitaryzmu. Nieprzypadkowo pierwsze konferencje dla środowiska akademickiego Krakowa, w kościele św. Floriana, Karol Wojtyła - młody wikary - poświęcił problematyce istoty człowieka, niejako wbrew realiom ówczesnej rzeczywistości, o których jedna z słuchaczek tychże konferencji napisała wiele lat później: „Rok 1949. W Polsce stalinizm, zniewolenie i indoktrynacja osiagają apogeum". Zapis tych wykładów, na wyraźną prośbę słuchaczy, Wojtyła przygotował i udostępnił potem studentom w formie maszynopisu. W roku 1999 maszynopis ten został wydany jako Rozważania o istocie człowieka ${ }^{9}$. Zacytujmy ostatnie zdania, którymi autor podsumował treść swoich konferencji, podkreślając że chrześcijański humanizm: „nie jest jakimś nagłym odwróceniem się ku człowiekowi w chrześcijaństwie, ale prostym i pełnym odkryciem prawdy o człowieku - tej prawdy, nad którą rozum ludzki pochyla się z całą wnikliwością, a którą Objawienie stawia w nowym, nadprzyrodzonym świetle i rozwiązuje przez prawdę o Bożym synostwie ludzkiej istoty"10.

Prace Wojtyły - filozofa i etyka - przynoszą w następnych latach dogłębne analizy człowieka jako osoby, zaś Wojtyły - duszpasterza i człowieka Kościoła - wyjaśnienia, uzasadnienia i drogi wprowadzania w codzienne życie osobowej istoty człowieczeństwa, w której wyraża się sens bycia przez każdego człowieka obrazem Boga. We wszystkich pracach Karol Wojtyła podkreśla, że podstawą personalistycznej wizji człowieka jest jego godność, wymagająca respektowania i obrony jako najwyższa wartość ludzka. Człowiek jako osoba spełnia się w bezwarunkowej miłości - darze, ofiarowywanej w prawdzie i wolności. Autor Osoby i czynu, Miłości i odpowiedzialności i wielu innych tekstów uczy dostrzegania godności w każdym, niezależnie od wieku, sytuacji, warunków, wyjaśnia błędne rozumienia i fałszywe interpretacje miłości. Uświadamia, jak bardzo od respektowania godności

${ }^{7}$ R. Buttiglione, Myśl Karola Wojtyly, przekł. J. Merecki, Lublin 1996, s. 44-45.

${ }^{8}$ T. Skawińska, Stowo wstępne, w: K. Wojtyła, Rozważania o istocie człowieka, Kraków 1999.

${ }_{9}$ K. Wojtyła, Rozważania o istocie człowieka, Kraków 1999.

10 Tamże, 127. 
i bezwarunkowego dla niej szacunku zależą więzi międzyludzkie, zdrowe wspólnoty, życie małżeńskie i rodzinne, struktury i procesy społeczne. Relacjonując w 1964 roku prace Soboru, w którym aktywnie uczestniczy jako jeden z Ojców Soboru biorący udział w redagowaniu wielu ważnych dokumentów, Karol Wojtyła wyjaśnia:

Uznawać godność człowieka oznacza stawianie wyżej jego samego niż wszystkiego, cokolwiek w widzialnym świecie od niego pochodzi [...]. Człowiek nie żyje dla techniki, cywilizacji czy nawet kultury, żyje natomiast przy ich pomocy, zachowując stale swoją własną celowość. Ta celowość wiąże się ściśle $\mathrm{z}$ prawdą, człowiek bowiem jest istotą rozumną, oraz z dobrem jako właściwym przedmiotem wolnej woli. [...]. Nie sposób uznawać godność człowieka, nie licząc się z tą celowością oraz na wskroś duchowym jej charakterem ${ }^{11}$.

W 10 lat po krakowskich konferencjach o istocie człowieka, już biskup Wojtyła, w ramach przygotowań do Soboru Watykańskiego II, który rozpocznie się w roku 1962, wysyła do Rzymu opracowanie dotyczące potrzeby wyraźnego określenia humanizmu chrześcijańskiego oraz jego znaczenia w świecie współczesnym.

Wiele lat później Wojciech Chudy - filozof i etyk, wybitny znawca i interpretator nauczana Jana Pawła II - wyrazi gorzką opinię: „Personalizm Wojtyły jest odpowiedzią na arogancję siły wobec prawdy, władzy państwa wobec osoby i arogancję arbitralnej wolności wobec solidarności"12. I dalej: „Personalizm Wojtyły jest w Polsce n i e d o c e n i o n y, jeśli za kryterium wziąć tkwiący w nim nowatorski ladunek myśli potencjalnie zdolny przeistoczyć teorię i praktykę życia ludzkiego"13.

Kardynał Karol Wojtyła, znany nie tylko w Polsce, ale po Soborze - także na świecie, jako gorący orędownik promowania idei humanizmu chrześcijańskiego w misji Kościoła i w życiu współczesnych ludzi, zostaje w 1978 roku wybrany Papieżem.

Wieloletnie zgłębianie problemu tożsamości człowieka i doświadczenie duszpasterskie w pracy z różnymi środowiskami zaowocowało bardzo dobrą znajomością współczesnego świata i człowieka, zrozumieniem jego sytuacji zewnętrznej i wewnętrznej. Jan Paweł II wiedział, że dojmującym

11 Tenże, Stużyć godności osoby ludzkiej, Przemówienie w Radio Watykańskim, 19.10.1964, w: K. Wojtyła, Odnowa Kościoła i świata. Refleksje soborowe, Kraków-Rzym 2011, s. 183-184.

${ }^{12}$ W. Chudy, Wprowadzenie, w: R. Buttiglione, Myśl Karola Wojtyly, przeł J. Merecki, Lublin 1996, s. 12.

13 Tamże, s. 18. 
przeżyciem ludzi na całym świecie jest lęk. Lęk wywołany rosnącymi zagrożeniami cywilizacyjnymi, ale głównie utratą sensu życia i perspektyw, lęk prowadzący do obrony ostatniego „bastionu” szans na lepsze życie - własnej wolności. Ojciec Święty wiedział, że współczesny człowiek nie wie, kim jest, boi się takich pytań, a oddalając się od Boga, zrywa więź z Chrystusem, która pozwoliłaby mu zrozumieć siebie i sens własnego życia. Niecałe pół roku po rozpoczęciu pontyfikatu, w marcu 1979 roku w pierwszej swojej encyklice Redemptor Hominis, stanowiącej fundament programowy całego pontyfikatu - Jan Paweł II pisze:

Człowiek nie może żyć bez miłości. Człowiek pozostaje dla siebie istotą niezrozumiałą, jego życie jest pozbawione sensu, jeśli nie objawi mu się Miłość, jeśli nie spotka się z Miłością, jeśli jej nie dotknie i nie uczyni w jakiś sposób swoją, jeśli nie znajdzie w niej żywego uczestnictwa i dlatego właśnie Chrystus - Odkupiciel, [...] objawia w pełni człowieka samemu człowiekowi (RH 10) ${ }^{14}$.

W dalszych partiach tego tekstu, poruszającego swą głębią i aktualnościa, znajomością współczesnego świata i człowieka, znajdujemy wiele ważnych diagnoz, wskazujących między innymi na przyczyny towarzyszących dziś człowiekowi lęków, dynamikę pojawiających się zagrożeń, trudności przeżywania wolności. Jan Pawel II, w świetle wiary wskazuje drogę wyjścia - konieczność przyjęcia przez współczesny świat zasad: prymatu etyki przed techniką, osoby przed rzeczą i ducha przed materią, odkrywania i podejmowania swojego ludzkiego powołania na drodze prawdy i miłości, zrozumienia „wolności” jako wolności do doskonalenia się, do bycia dobrym, wolności w służbie prawdy i miłości.

\section{Jana Pawła II uczenie nowego humanizmu}

Walka Jana Pawła II o godność człowieka, jej promowanie, rozumienie i respektowanie, o przysługujący każdemu człowiekowi szacunek, pokazywała współczesnemu światu, na czym polega nowy humanizm.

Jan Paweł II wiedział, że pytania o sens ludzkiego życia, o własną tożsamość, o prawdę i wolność, stawiają sobie głównie ludzie młodzi, którzy od odnalezionej (bądź nie) wiarygodnej odpowiedzi uzależniają wiele swoich życiowych decyzji. Dlatego to do nich często i dobitnie mówi o wielkości człowieczeństwa, zawsze wyrażając zrozumienie ich zagubienia i lę-

14 Jan Paweł II, Encyklika Redemptor Hominis, w: Encykliki Ojca Świętego Jana Pawła II, Kraków 1996 - w tekście RH z odnośnym numerem. 
ków. Wymownym przykładem przybliżania młodym nowego humanizmu może być fragment $\mathrm{z}$ jednej z homilii wygłoszonych do młodzieży w roku 1983. Fragment ten zawiera przedstawioną w niesłychanie prostej i skondensowanej formie charakterystykę współczesnej sytuacji człowieka, jego potrzeb, tęsknot i trudności, a zarazem odpowiedź wyrastającą z chrześcijańskiego widzenia człowieka, precyzyjne wyjaśnienie, kim jest, a kim nie jest człowiek.

Wiem, że często stawiacie sobie pytanie, jak przeżyć swoje życie z poczuciem, iż się go nie zmarnowało. [...] Wiem, że jest w was pragnienie szlachetnych ideałów, bez względu na ich cenę, i że nie chcecie życia szarego, złożonego z małych i dużych zdrad waszego sumienia ludzi młodych i chrześcijan. [...] nie wystarczy patrzeć na tyle zła, które odkrywacie wokół siebie, ani też biernie go opłakiwać. Nie wystarcza również krytyka zła. Nie znajdziecie też żadnego rozwiązania, gdy w obliczu zła uznacie się za bezsilnych czy zwyciężonych i gdy dacie się ponieść rozpaczy. Chrystus wzywa was, żebyście opowiedzieli się po stronie dobra, po stronie zniszczenia egoizmu i grzechu we wszystkich jego postaciach. Chce, abyście budowali społeczeństwo, w którym kultywuje się wartości moralne, wartości, które Bóg pragnie zobaczyć w sercu i w życiu człowieka. [...] Ta droga zaangażowania na rzecz drugiego człowieka nie jest łatwa. Pracować dla wyniesienia człowieka i po to, by godność jego była zawsze uznawana i szanowana - to zadanie bardzo wymagające ${ }^{15}$.

Jan Paweł II zachęca młodych ludzi do wysiłku, pokazując im pozytywną wartość człowieka i człowieczeństwa. Mówi dalej: „warto podejmować wysiłki, aby stać się lepszym; [...] Warto, ponieważ [...] człowiek nie jest biednym stworzeniem, które żyje, cierpi, cieszy się, jest wyzyskiwane i śmiercią kończy swoje życie; ale jest istotą, którą Bóg kocha i chce, by była kochana. Tak, nie tylko chce, by była szanowana - jest to pierwszy i podstawowy krok - ale żeby była kochana przez istoty sobie podobne"16. Przytoczony fragment pokazuje, jak Jan Paweł II wprowadzał współczesnych młodych ludzi w myślenie z perspektywy nowego humanizmu, który uważał za klucz do ratowania współczesnego świata i człowieka.

Stałym wyzwaniem przez wszystkie lata pontyfikatu Jana Pawła II pozostała walka o godność człowieka (kontynuowana z całą determinacją przez Benedykta XVI). Była to i jest walka nie tylko z systemami totalitarnymi, ale $\mathrm{z}$ rosnącą w siłę kulturą konsumpcyjna, z nowymi formami wyzysku i dyskryminacji, z rosnącymi egoizmami jednostkowymi i grupowymi. Egoizmy

15 Jan Paweł II, Homilie na niedziele i święta, Rok ABC, Kraków 2007, s. 596.

16 Tamże, s. 597. 
te degradują człowieka w imię bezwzględnego dążenia do zysku, sprzyjają rozmywaniu się chrześcijaństwa $\mathrm{w}$ coraz bardziej poddającej się zeświecczeniu kulturze Zachodu. U podstaw tych wyzwań leży słabnięcie wrażliwości na osobę ludzką, co jest wynikiem praktycznego urządzania i teoretycznego uzasadniania „świata bez Boga”. Człowiek współczesny przełomu II i III tysiąclecia nie tylko był i jest atakowany w swojej ludzkiej godności, coraz częściej brutalnie jej pozbawiany, ale nierzadko, dla różnych profitów, dobrowolnie z niej rezygnuje.

Ostatnią encykliką napisaną przez Jana Pawła II w XX wieku (w roku 1996), w dwudziestym roku pontyfikatu, była encyklika poświęcona wciąż kontrowersyjnej według wielu krytyków Kościoła relacji wiary i rozumu (Fides et ratio). Jan Paweł II szeroko wyjaśnia w niej niezbędność ścisłej więzi obu dróg poznania prawdy, szczególnie prawdy o człowieku. Zgodnie z chrześcijańską koncepcją człowieka do uwzględniania tej dwoistości człowiek został odpowiednio wyposażony w niezbędne zdolności, sprawności, a do jej respektowania został powołany. Tekst ten zawiera ważne treści uwrażliwiające na potrzebę kształcenia mądrości, na zagrożenia bezkrytyczną i mało refleksyjną postawą wobec współczesnych prądów intelektualnych (wśród nich przede wszystkim scjentyzmu, nihilizmu, pragmatyzmu, postmodernizmu). Jan Paweł II zwraca uwagę, iż prądy te wyrażają stanowisko humanizmu ateistycznego. Rzetelne ukazywanie ich sensu jest zobowiązaniem dla wszystkich zajmujących się kształceniem, jako przygotowaniem do poznawania prawdy. Jak twierdzi amerykański badacz pontyfikatu Jana Pawła II G. Weigel - i ta encyklika wzywa człowieka współczesnego do odwagi - tym razem do nielękania się odwoływania się do rozumu w kontekście wiary, niepoddawania się presji fałszywego wyboru: albo wiara, albo rozum. Przytoczmy fragment tekstu tej encykliki: „Kościół ma na uwadze dwa cele jednocześnie - obronę godności człowieka i głoszenie ewangelicznego orędzia. Najpilniejszym warunkiem realizacji tych zadań jest dziś doprowadzenie ludzi do odkrycia własnej zdolności poznania prawdy oraz tęsknoty za najgłębszym i ostatecznym sensem istnienia" (FeR 102) ${ }^{17}$. I nieco dalej:

Wszystkich proszę, aby starali się dostrzec wnętrze człowieka, którego Chrystus zbawił przez tajemnicę swojej miłości, oraz głębię jego nieustannego poszukiwania prawdy i sensu. Różne systemy filozoficzne wpoiły mu złudne przekonanie, że jest absolutnym panem samego siebie, że może samodzielnie decydować o swoim losie i przyszłości, polegając wyłącznie na sobie i na własnych siłach. Wielkość człowieka nigdy nie urzeczywistni się w ten sposób

17 Tenże, Encyklika Fides et Ratio o relacjach między wiarą i rozumem, Poznań 1998 w tekście FeR z odnośnym numerem. 
Stanie się to możliwe tylko wówczas, gdy człowiek postanowi zakorzenić się w prawdzie (FeR 107).

Człowiek widziany w perspektywie nowego humanizmu Jana Pawła II jest otwarty na obydwie drogi dochodzenia do prawdy - drogę rozumu i wiary.

\section{Nowy humanizm w rzeczywistości wychowawczej szkoły}

Wprowadzanie w rzeczywistość wychowania szkolnego nowego humanizmu wymaga kształcenia rzetelnych kompetencji, które umożliwiałyby i wspomagały integralny rozwój każdego ucznia. Celem jest więc rozwój ucznia umożliwiający mu odkrycie własnego potencjału i zaangażowanie wszystkich możliwości i zdolności w jego realizację. Równie ważne jest jednak stwarzanie warunków do respektowania godności każdego członka społeczności szkolnej, do kształcenia w uczniach świadomości i postawy szacunku wobec godności własnej i innych. Organizacja życia szkoły powinna zapewniać sytuację, w której wszyscy czują się szanowani, ważni, potrzebni, doceniani, wspierani w realizacji wymagań niezbędnych do rozwoju, wspomagani w sytuacjach trudnych.

Dziś jest to szczególnie trudne i pilne wyzwanie. Współczesny świat wywiera ogromną presję na środowiska oświatowe, w tym głównie na szkoły, by stały się wyłącznie miejscem przygotowywania ludzi do funkcjonowania w sytuacjach rynkowych, do ról konsumentów i producentów, do sprawnego poruszania się w rzeczywistości nowych technologii. Zasadniczym celem oświaty staje się kształcenie dla potrzeb rynku pracy. Podmiotami stają się więc rynek towarów, usług, rynek pracy, które wymuszają na człowieku rolę klienta nieustannie aspirującego do zdobycia a potem wzmocnienia za każdą cenę swojej pozycji na rynku, które kształcą do bezwzględnej konkurencji w walce o jakiekolwiek korzyści ${ }^{18}$. Człowiek jako podmiot, osoba o bezwarunkowej godności, której na mocy samego faktu bycia człowiekiem przysługują określone prawa, znika z powszechnej świadomości, jest coraz bardziej wypierany ze współczesnej kultury. Nawet jeśli artyści i intelektualiści podejmują temat dramatycznego uprzedmiotawiania człowieka, nie pozostawiają ani złudzeń co do szans na zmianę, ani miejsca na nadzieję. Wzmacniają poczucie beznadziei i skazania na nieuchronną porażkę każdego, kto wykazuje „wiarę w ideały” i wartości wyższe. Dotyczy

18 Jest to efekt umacniającej swoje wpływy między innymi na edukację ideologii neoliberalizmu. Por. E. Potulicka, J. Rutkowiak, Neoliberalne uwikłania edukacji, Kraków 2012. 
to $\mathrm{w}$ pierwszym rzędzie młodego pokolenia, specjalnie uwrażliwionego na ideały i wartości, radykalnego w ocenie ich wiarygodności a równocześnie poszukującego własnej tożsamości. Dzisiejsza szkoła na ogół nie radzi sobie także $\mathrm{z}$ kształceniem podmiotowości i jej ochroną. Lawina przepisów, wymagań, związanych z tworzeniem dokumentacji, pozostawia coraz mniej miejsca dla ludzi, ich potrzeb, czasu na indywidualny kontakt, sytuacje sprzyjające wzajemnemu wspieraniu się w rozwoju, motywowaniu do wysiłku, dzieleniu radości. Poruszające opinię publiczną doniesienia o szkolnych problemach wychowawczych dotyczą często zachowań świadczących o wzajemnym braku szacunku, świadomym atakowaniu godności kolegów i wychowawców, cynicznym ich poniżaniu.

Myślenie i działanie w świetle nowego humanizmu Jana Pawła oznacza bronienie się przed uleganiem dominującym w otoczeniu tendencjom. Bronienie się oznacza tu zarówno pracę programową - kształcenie potrzeby i umiejętności poznawania prawdy, w tym - budzenie i rozwijanie ciekawości poznawczej, dostrzegania i realizowania dobra jednostkowego i wspólnego, odkrywania i tworzenia piękna, jak i styl wychowawczego działania. Styl ten decyduje o atmosferze chroniącej osobowy - oparty na uznaniu bezwzględnej godności każdego człowieka - wymiar rzeczywistości wychowawczej.

Szkolnictwo polskie w ostatnich latach stara się niejako nadrabiać opóźnienia w racjonalnym budowaniu oświaty, zablokowanym przez powojenna sytuację polityczna. Wydaje się, że jego przedstawiciele mogliby wiele skorzystać, sięgając do wypowiedzi Jana Pawła II, kierowanych w latach 80. XX wieku do pedagogicznych środowisk Zachodu - w czasie, kiedy środowiska te spotykały się z problemami podobnymi do dzisiejszych problemów polskiej rzeczywistości wychowawczej. Przykładem może być przemówienie Jana Pawła II do nauczycieli i studentów w czasie pielgrzymki do Wielkiej Brytanii w roku 1982. Przywołajmy fragmenty tego wystąpienia:

Wydaje się, że w czasach współczesnych powodzenie danego programu czy systemu wychowania oceniane jest $\mathrm{w}$ dużej mierze na podstawie uznania kwalifikacji, jakich dostarcza tym, dla których celem jest perspektywa kariery. [...] Taki sposób widzenia zachęcał do „zewnętrznej” tendencji w wychowaniu - co nie jest samo w sobie czymś złym. Brakowało tu jednak pewnej równowagi czy perspektywy - perspektywy całej osoby ludzkiej, zarówno jej wewnętrznego ,ja”, jak i jej zewnętrznych aspiracji. [...] Być wykształconym znaczy być lepiej przygotowanym do życia, posiadać większą zdolność oceniania jego wartości, tego, co ma ono do zaoferowania i co w zamian człowiek może zaofiarować ludzkiej społeczności. Gdybyśmy zatem nasze możliwości i nowoczesne metody wychowawcze zastosowali do tej filozofii, moglibyśmy ofiarować naszym studentom i uczniom trwałe wartości jako antidotum na tak 
częste i bliskie niebezpieczeństwo frustracji i zniechęcenia, by nie wspomnieć już o niepewności jutra ${ }^{19}$.

Jan Paweł II zwracał uwagę środowisk pedagogicznych na potrzebę rozpoczynania prac nad edukacją od koncepcji człowieka. W tym samym roku 1982, we Włoszech mówił:

Edukacja jest zjawiskiem typowo ludzkim, ponieważ tylko człowiek może i powinien się kształcić. [...] Oczywiście, pojęcie edukacji zależy od koncepcji człowieka i jego przeznaczenia. Tylko wtedy, gdy dobrze się zrozumie, kim jest człowiek sam w sobie i co jest ostatecznym celem ludzkiego życia, poprawnie i logicznie wyłania się problem, jak prowadzić człowieka do osiagnięcia przezeń swego osobistego celu. [...] w kształceniu należy zwracać większą uwagę na wymiar duchowy. Celem kształcenia musi być zawsze to, by człowiek stawał się dojrzalszy, to znaczy by stawał się osobą, która doprowadzi do doskonałości i w pełni zrealizuje wszystkie swoje możliwości i zdolności. [...] Przeciwieństwem takiej wizji jest społeczeństwo hedonistyczne i konsumpcyjne starające się o wyeliminowanie $\mathrm{z}$ bytu człowieka wymiaru duchowego i tym samym pozbawiające się jakiegokolwiek autentycznego modelu człowieczeństwa, które mogłoby zaproponować swoim członkom²0.

\section{Konkluzje}

Jan Paweł II wielokrotnie wypowiadał się wprost o niezwykle ważnej roli szkoły, powołaniu nauczycieli i wychowawców, o potrzebie stawiania na pierwszym miejscu celów wychowawczych. W zaproponowanych tu rozważaniach chodziło jednak o inne ujęcie; o spojrzenie na rzeczywistość wychowawczą z perspektywy programu nowego humanizmu Jana Pawła II. Zaproponowane w nim widzenie człowieka jest szczególnie ważne w warunkach współczesnej sytuacji kulturowej - w świecie coraz bardziej podzielonym i skłóconym, zafascynowanym technologicznymi i ekonomicznymi kryteriami rozwoju, traktującym człowieka instrumentalnie i przedmiotowo, wreszcie - w rzeczywistości coraz bardziej zsekularyzowanej, oddalającej się od Boga. Jest to codzienne doświadczenie coraz liczniejszych środowisk, grup i jednostek, tym samym - doświadczenie dzisiejszych wychowaw-

19 Jan Paweł II, Przemówienie do nauczycieli i studentów Kolegium św. Andrzeja w Glasgow, 1.06.1982. [3.4], „L'Osservatore Romano” 10 (1982), s. 29.

${ }^{20}$ Tenże, $W$ stużbie prawdy $i$ wolności, Przemówienie na Uniwersytecie w Padwie, „L'Osservatore Romano” 9 (1982), s. 23. 
ców a także dzisiejszej szkoły. Kluczem do myślenia o edukacji jest w tym kontekście przyjmowana świadomie i dogłębnie rozumiana we wszystkich swych konsekwencjach koncepcja człowieka. Perspektywa nowego humanizmu Jana Pawła II otwiera przestrzeń dla budowania i realizowania programów wychowawczych, w których punktem wyjścia jest godność każdego człowieka i przysługujący ze względu na nią bezwarunkowy szacunek, ukazywanie wartości prawdy, dobra i piękna, roli dążenia do tych wartości w rozwoju człowieka, znaczenie bycia osobą jako istotą rozumną i wolna, odpowiedzialną za realizację wartości wyższych. W kulturze o korzeniach chrześcijańskich, jaką jest kultura polska, i szerzej - kultura europejska, ważne jest ukazywanie źródeł takiego myślenia o człowieku w świetle wiary chrześcijańskiej i rzetelne wyjaśnianie istoty humanizmu chrześcijańskiego. Perspektywa ta stwarza szansę oparcia wychowawczej pracy z młodzieżą na bliskim jej poszukiwaniu tożsamości, sensu wysiłku w pracy nad własnym rozwojem, bezinteresownych więzi międzyludzkich.

\section{New Humanism of John Paul II as a Prospect for Contemporary School and Educational Reality (Summary)}

Lack of a bright concept of a human being is characteristic of contemporary social life - including education. Social practice indicates that the most frequently accepted ideal is that of a man with numerous competences and qualifications useful on the labour market. Nevertheless, that kind of a man is not interested in spiritual development, conscious choice of values, reflection on the point and way of life. The effect - egoism, fighting for position, susceptibility for manipulation, consumption motivation. The author reviews and analyses "new humanism" - a programme introduced by John Paul II as an answer to the condition of contemporary culture. John Paul II emphasized the need of differentiating new humanism from humanism as a more general and casual keyword at present. "New humanism" combines personalistic anthropology and Christian humanism. The text is finished with a fragment dedicated to the way of explaining "new humanism" by John Paul II and conclusions for educational practice deriving from it.

Keywords: personalistic anthropology; humanism; Christian humanism; new humanism. 


\section{Nowy humanizm Jana Pawła II jako perspektywa dla współczesnej rzeczywistości szkolnej i wychowawczej (Streszczenie)}

Współczesne życie społeczne, w tym - edukacja, charakteryzują się brakiem jasnej koncepcji człowieka. Praktyka społeczna wskazuje, że przyjmowanym najczęściej ideałem jest człowiek o wielu kompetencjach i kwalifikacjach przydatnych na rynku pracy. Jest to jednak człowiek niezainteresowany swoim rozwojem duchowym, świadomym wybieraniem wartości, refleksją o sensie i celu życia. Efektem jest egoizm, walka o pozycję, podatność na manipulację, motywacja konsumpcyjna. Autorka omawia i analizuje ,nowy humanizm” - program wprowadzony przez Jana Pawła II jako odpowiedź na stan współczesnej kultury. Jan Paweł II podkreślał potrzebę odróżniania nowego humanizmu od humanizmu, jako coraz bardziej ogólnikowego i niezobowiązującego dziś hasła. „Nowy humanizm” łączy antropologię personalistyczną z chrześcijańskim humanizmem. Tekst kończy fragment poświęcony sposobowi wyjaśniania przez Jana Pawła II „nowego humanizmu” i płynącym stąd wnioskom dla praktyki wychowawczej.

Słowa kluczowe: antropologia personalistyczna; humanizm; humanizm chrześcijański; nowy humanizm. 
